\title{
The outcomes of open reduction by the medial approach for developmental dysplasia of the hip in the 3-18 months old patients
}

\author{
Tülin Türközü ${ }^{1 *}$, Savaş Güner ${ }^{2}$, Mehmet Fethi Ceylan $^{3}$, Necip Güven $^{1}$ \\ ${ }^{1}$ Republic of Turkey Ministry of Health, Health Sciences University, Van Education and Research Hospital Department \\ of Trauma and Orthopedic Surgery, Van, Turkey \\ ${ }^{2}$ Yuzuncu Yil University Medical School Hospital, Department of Trauma and Orthopedic Surgery, Van, Turkey \\ ${ }^{3}$ Inonu University, Facult of Medicine, Department of Trauma and Orthopedic Surgery, Malatya
}

\begin{abstract}
This study has aimed to evaluate the outcomes of open reduction technique by the medial approach performed in the 3-18 months old infants.

The patients who underwent an open reduction by the medial approach for typical dysplasia of hip between the years 2007 2011 were screened retrospectively. The study included 28 hips of 19 patients. The correction percentage of acetabular index was calculated by acetabular angle measurements performed prior to operation and at the last control examination. Avascular necrosis (AVN) was classified by the criteria of Kalamchi-MacEwen while radiological and clinical evaluations were performed using Severin and McKay criteria.

The mean age at surgery was 12.1 months (3-18 months) while mean follow-up period duration was found 18.6 months (648 months). According to Severin radiological criteria, $9(32.1 \%)$ and $9(32.1 \%)$ hips were evaluated as excellent and good, respectively. Whereas, according to the evaluation based on McKay criteria, $22(78.6 \%)$ and $6(21.4 \%)$ hips were found excellent and good, respectively. Avascular necrosis (AVN) of the femoral head was encountered in 3 (10.7\%) of the 28 hips. According to the criteria of Kalamchi-MacEwen Classification; 2 and 1 hips revealed Type I and Type 4 avascular necrosis, respectively.

We have encountered according to outcomes data of this study that open reduction technique by the medial approach for treatment of developmental dysplasia of the hip (DDH) presented more successful clinical and radiological outcomes in the 3-12 months old infants compared with its application in the 13-18 months old infants.
\end{abstract}

Key Words: Open reduction, developmental dysplasia of the hip, avascular necrosis, medial approach

\section{Introduction}

Open reduction by the medial approach is a surgical approach accepted as a treatment modal for DDH and especially preferred in the infants between 6-18 months old of age. Medial approach facilitates to reach and liberate the structures which constrict reduction (joint capsule, transverse acetabular ligament, pulvinar and iliopsoas tendons) compared with other techniques. Open reduction by the medial approach presents important advantages such as lesser tissue dissection, lower blood loss, cosmetically more favorable cutaneous incision, shorter surgical duration and bilateral applicability in an identical session.

The most important disadvantages of this technique are inability to evaluate the pathological changes in the superior acetabulum and infeasibility of capsulography for stable reduction $(1,2)$.

In this study, we have evaluated the clinical and radiological outcomes, presence of potential complications such as avascular necrosis and also need to an additional surgery in the patients who underwent open reduction by the medial approach for DDH in our clinic.

\section{Materials and methods}

The study was started after receiving the approval from The Ethics Committee. In the study, we have retrospectively screened the patients who were performed open reduction by the medial approach as described by Ferguson, for a typical 
dysplasia of the hip between the years 2007-2011 in our clinic. The hospital file records of the 19 patients who met the inclusion criteria were analyzed. These patients consisted of $15(78.9 \%)$ female and $4(21.1 \%)$ male patients. Of the patients, $4(21.1 \%), 3(15.8 \%)$ and $12(63.1 \%)$ had right-sided, left-sided and bilateral $\mathrm{DDH}$, respectively. Since single-sided hips of 3 patients with bilateral DDH were operated by the anterior approach in an external medical center, these hips were excluded from the study. Totally 28 hips operated by the medial approach were included in the study.

Surgical Technique: During the medial approach, following sterile staining and draping under general anaesthesia, the patient was laid down in the supine position while the hips were in flexion, abduction and external rotation. An approximately $3 \mathrm{~cm}$ long longitudinal incision was performed starting from $1-1.5 \mathrm{~cm}$ distal to the pubic tubercle and over adductor longus muscle. Adductor tenotomy was performed passing through subcutaneous layers. A blunt entry was conducted through the muscle plane created placing adductor longus and brevis muscles in anterior and with adductor magnus and gracilis muscles in posterior. In deep plane, Lesser trochanter was palpated and iliopsoas tendon was dissected from adhesion site to the lesser trochanter. Following, the joint capsule was exposed bluntly and revealed longitudinally from inferomedial aspect to expose the hip joint. At this stage, its avoided to injure medial circumflex artery and its branches. Ligamentum Teres tendon was excised and intra articular pulvinar tissue was removed. Following control of the reduction, only subcutaneous tissue and skin were sutured, the pelvipedal casting was applied to the hips in their most stable position. This stability was generally achieved in $30^{\circ}-40^{\circ}$ abduction, $90^{\circ}-100^{\circ}$ flexion and $10^{\circ}-15^{\circ}$ internal rotation. Following totally 3 months application of casting, Dennis-Brown Bar was used during whole day and night for 3 months and then during only night time for 3 months.

Evaluation: In the last control examination of the patients, their hips were assessed and pelvis AP radiographs were taken and acetabular index measurements were performed. Acetabular index values were measured preoperatively $\left(\mathrm{AI}_{1}\right)$ and at the last control examination $\left(\mathrm{AI}_{2}\right)$, correction percentage of acetabular index $\left(\mathrm{AI}_{1}-\mathrm{AI}_{2} / \mathrm{AI}_{1}\right)$ was accepted as the rating scale (3). Postoperatively emerging complications and performed additional interventions were recorded (Table 1).
Severin's Criteria was used for radiological evaluation (4). Clinical evaluation was performed based on modified McKay's assessment criteria (5). Avascular necrosis (AVN) as one of the frequent complications was evaluated according to Kalamachi and MacEwen's criteria (6) (Table 1).

The data obtained in the study were analyzed using definitive statistics, frequence tables and correlation coefficients were calculated. Student's t-test (for matched samples) was performed in comparison between preoperative and postoperative values with respect to acetabular index as a variable. Statistical significance level was accepted as $p<0.05$. Statistical analysis was performed using SPSS (16.0) statistical pocket software.

\section{Results}

It was encountered that 15 and 13 hips were operated within the age ranges of 3-12 and 13-18 months old, respectively. The mean age at surgery was 12.1 months (3-18 months) with a mean follow-up period duration of 18.6 months (6-48 months). In our study, mean preoperative acetabular index of the patients was $39.1^{\circ}\left(32^{\circ}\right.$ $50^{\circ}$ ) while mean value of the acetabular indices at the last control examination was found as $30.5^{\circ}$ $\left(18^{\circ}-48^{\circ}\right)$ (The samples from the cases are presented in Figure 1 and Figure 2). No complication was monitored in 20 hips in the postoperative period, maceration of the skin and superficial infection developed in 2 hips (7.2\%). Subluxation developed in $3(10.7 \%)$ hips while avascular necrosis emerged in 3 hips $(10.7 \%)$ (According to Kalamchi-MacEwen's classification; 2 and 1 hips were assessed as Type 1 and Type 4, respectively). Of the 28 hips, no secondary intervention was needed in 18 hips whereas arthrography with scopic guidance was performed in 2 hips with development of subluxation and limited range of motion and concentric reduction between femoral head and acetabulum was achieved, and also considered to follow-up by applying pelvipedal casting. Totally 8 hips $(28.6 \%)$ in whom no improvement could be achieved with respect to acetabular index by the medial approach open reduction and also subluxation developed were diagnosed with the indication of Salter innominate osteotomy (SIO). Of those, 2 hips were in the group operated within the age range of 3-12 months old at surgery whereas 6 hips were in the group operated within the age range of 13-18 months old (Table 2). 
Table 1. Data of the patients

\begin{tabular}{|c|c|c|c|c|c|c|c|c|c|c|c|}
\hline No & Sex & $\begin{array}{c}\text { Age at } \\
\text { surgery } \\
\text { (months) }\end{array}$ & $\begin{array}{c}\text { Follow-up } \\
\text { duration } \\
\text { (months) }\end{array}$ & $\begin{array}{c}\text { Operated } \\
\text { side }\end{array}$ & AI1 & AI2 & Complication & $\begin{array}{l}\text { Additional } \\
\text { operation }\end{array}$ & $\begin{array}{c}\text { Kalamchi's } \\
\text { Criteria }\end{array}$ & $\begin{array}{c}\text { Severin's } \\
\text { Criteria }\end{array}$ & $\begin{array}{l}\text { McKay's } \\
\text { Criteria }\end{array}$ \\
\hline 1 & $\mathrm{~F}$ & 13 & 13 & Left & 32 & 30 & AVN & - & 4 & 3 & 2 \\
\hline 2 & $\mathrm{~F}$ & 18 & 10 & Right & 40 & 30 & $\begin{array}{l}\text { Limited } \\
\text { range of } \\
\text { motion }\end{array}$ & - & - & 3 & 2 \\
\hline 2 & & & & Left & 42 & 32 & Subluxation & - & - & 4 & 1 \\
\hline 3 & $\mathrm{~F}$ & 11 & 11 & Left & 50 & 48 & AVN & $\mathrm{SIO}$ & 1 & 3 & 1 \\
\hline 4 & $\mathrm{~F}$ & 17 & 9 & Right & 42 & 42 & Subluxation & SIO & - & 4 & 2 \\
\hline 5 & $\mathrm{~F}$ & 3 & 6 & Right & 36 & 22 & $\begin{array}{c}\text { Superficial } \\
\text { infection }\end{array}$ & - & - & 1 & 1 \\
\hline 6 & $\mathrm{~F}$ & 11 & 12 & Right & 40 & 32 & - & - & - & 2 & 2 \\
\hline 6 & & & & Left & 36 & 32 & - & - & - & 2 & 1 \\
\hline 7 & $F$ & 17 & 42 & Right & 40 & 34 & - & SIO & - & 3 & 1 \\
\hline 7 & & & & Left & 46 & 40 & $\begin{array}{c}\text { Superficial } \\
\text { infection }\end{array}$ & SIO & - & 3 & 1 \\
\hline 8 & $\mathrm{M}$ & 14 & 12 & Left & 34 & 30 & - & - & - & 2 & 1 \\
\hline 9 & $\mathrm{~F}$ & 9 & 15 & Left & 40 & 32 & AVN & SIO & 1 & 2 & 1 \\
\hline 10 & $\mathrm{M}$ & 9 & 17 & Right & 34 & 28 & - & - & - & 2 & 1 \\
\hline 10 & & & & Left & 32 & 22 & - & - & - & 1 & 1 \\
\hline 11 & $\mathrm{~F}$ & 13 & 16 & Right & 40 & 26 & - & - & - & 1 & 1 \\
\hline 12 & $\mathrm{~F}$ & 14 & 7 & Right & 48 & 46 & Subluxation & SIO & - & 4 & 2 \\
\hline 12 & & & & Left & 48 & 46 & - & SIO & - & 3 & 1 \\
\hline 13 & $\mathrm{~F}$ & 11 & 24 & Left & 32 & 24 & - & - & - & 1 & 1 \\
\hline 14 & $\mathrm{~F}$ & 6 & 11 & Right & 32 & 22 & - & - & - & 1 & 1 \\
\hline 14 & & & & Left & 34 & 22 & - & - & - & 1 & 1 \\
\hline 15 & $\mathrm{~F}$ & 9 & 37 & Right & 40 & 28 & - & - & - & 2 & 1 \\
\hline 15 & & & & Left & 40 & 24 & - & - & - & 1 & 1 \\
\hline 16 & $\mathrm{M}$ & 12 & 48 & Right & 40 & 26 & - & - & - & 2 & 2 \\
\hline 16 & & & & Left & 40 & 18 & - & - & - & 1 & 1 \\
\hline 17 & $\mathrm{~F}$ & 12 & 24 & Left & 40 & 26 & - & - & - & 2 & 1 \\
\hline 18 & F & 16 & 24 & Right & 40 & 30 & - & - & - & 2 & 1 \\
\hline 18 & & & & Left & 40 & 26 & - & - & - & 1 & 1 \\
\hline 19 & $\mathrm{M}$ & 15 & 15 & Right & 38 & 36 & - & SIO & - & 3 & 1 \\
\hline
\end{tabular}

Table 2. The rates of additional surgical interventions in the evaluated hips

\begin{tabular}{lccl}
\hline $\begin{array}{l}\text { Age of } \\
\text { Patients }\end{array}$ & $\begin{array}{l}\text { Number of } \\
\text { the hips }\end{array}$ & $\begin{array}{l}\text { Additional } \\
\text { Surgery (Sİ) }\end{array}$ & $\% *$ \\
\hline 3-12 months & 15 & 2 & 7.15 \\
13-18 months & 13 & 6 & 21.45 \\
3-18 months & 28 & 8 & 28.6 \\
\hline
\end{tabular}

${ }^{*}$ The calculation was based on total number of hips.

A statistically significant difference was found between preoperative and postoperative acetabular index values $(p<0.05)$. The difference between mean preoperative and postoperative acetabular index values was calculated $8.643 \pm 1.008$. This difference was more remarkable in the hips operated within the age range of 3-12 months old. A statistically significant correlation was determined between correction percentage of acetabular index and the parameters follow-up duration and age atsurgery. The correlation between correction percentage of acetabular index and follow-up duration was encountered as 0.453 $(p<0.01)$ whereas correlation between correction percentage of acetabular index and age atsurgery was determined as $-0.411(p<0.01)$. These results suggest that correction percentage of acetabular index is positively correlated with follow-up duration while it is negatively correlated with the age at operation. 

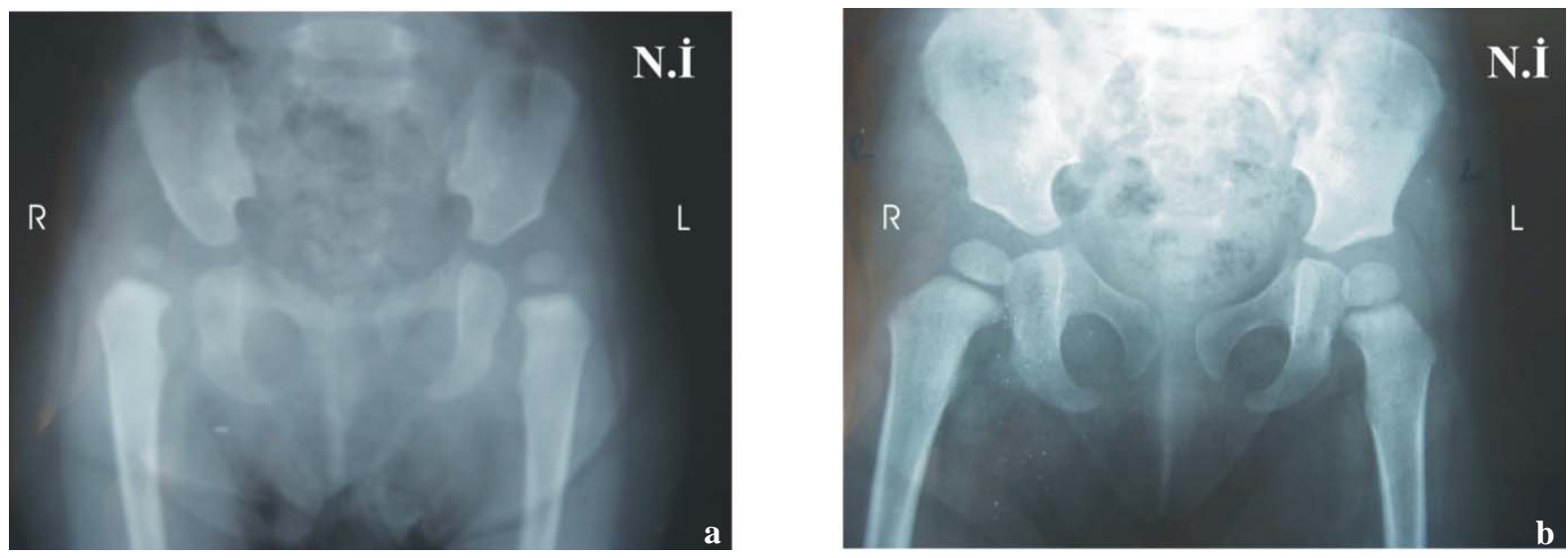

Fig. 1. Preoperative (a) and postoperative 16th month graphy (b) of the 13-month-old female patient.
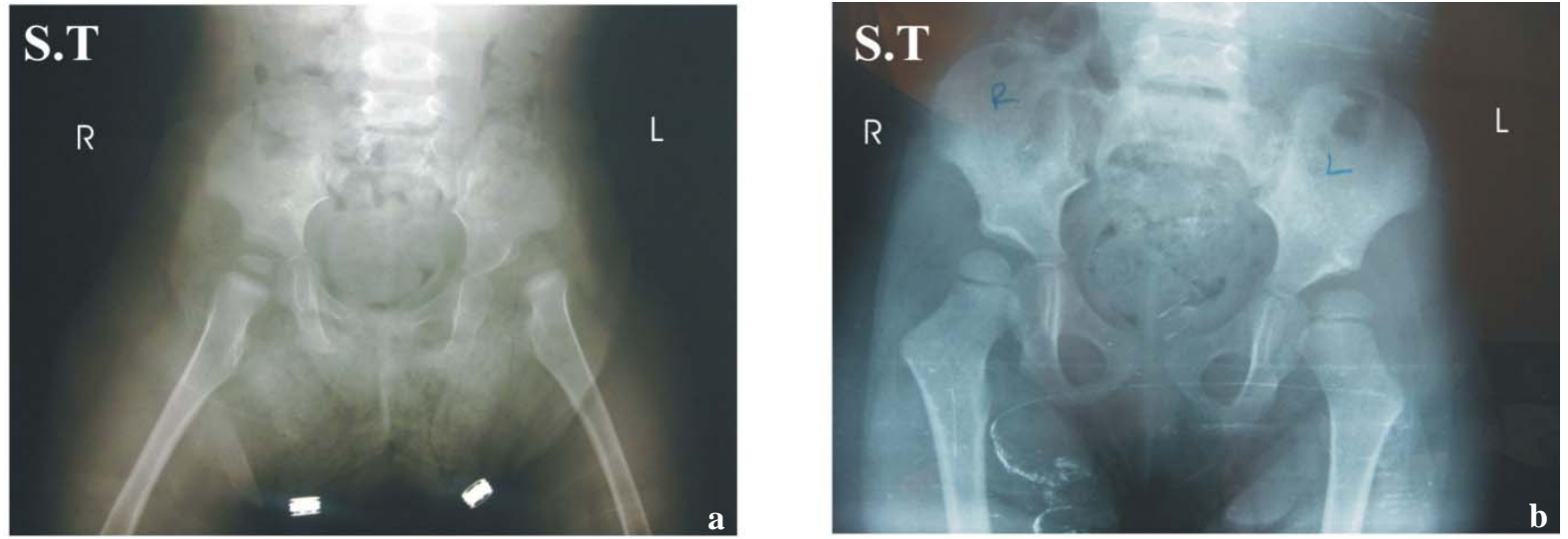

Fig. 2. Preoperative (a) and postoperative 24th month graphy (b) of the 12-month-old female patient.

Table 3. The evaluation of the patients according to Severin's Classification

\begin{tabular}{ccccccc}
\hline Severin Class & Group 1 (Excellent) & $\begin{array}{c}\text { Group } 2 \\
\text { (Good) }\end{array}$ & $\begin{array}{c}\text { Group 3 } \\
\text { (Mediate) }\end{array}$ & $\begin{array}{c}\text { Group } 4 \\
\text { (Poor) }\end{array}$ & $\begin{array}{c}\text { Group } 5 \\
\text { (Poor) }\end{array}$ & $\begin{array}{c}\text { Group 6 } \\
\text { (Poor) }\end{array}$ \\
\hline 3-12 months & 7 hips & 7 hips & 1 hip & - & - & - \\
13-18 months & 2 hips & 2 hips & 6 hips & 3 hips & - & - \\
\hline Total & 9 hips & 9 hips & 7 hips & 3 hips & - & - \\
& $(32.1 \%)$ & $(32.1 \%)$ & $(25.0 \%)$ & $(10.8 \%)$ & & \\
\hline
\end{tabular}

According to evaluation by Severin's radiological criteria, 9 (32.1\%), 9 (32.1\%), $7(25.0 \%)$ and 3 $(10.8 \%)$ hips were identified as excellent, good, moderate and poor, respectively. The most satisfactory outcomes were obtained in the operated hip within the age range of 3-12 months old (Table 3). In the evaluation based on modified McKay's Criteria; $22(78.6 \%)$ and $6(21.4 \%)$ hips were found excellent and good, respectively.

\section{Discussion}

In treatment of DDH, it is essential to achieve a stable and concentric reduction in early age for development of femoral head and acetabulum with normal values. Therefore, all structures which prevents reduction should be intervented to obtain concentric reduction. Medial approach facilitates and fasten to reach these structures. Two major and critical complications which can be experienced by this approach are insufficient hip stability after reduction and avascular necrosis due to injury of medial circumflex femoral artery (7). It has been reported that this technique was applied more successfully in the infants younger than 12 months old of age although it is commonly performed in the infants below 18 months of age (2,7-9). Our findings also support data obtained by the other studies in the literature. Castillo and Shearman (8) have operated 26 hips in their case of series and obtained the most 
favorable outcomes in the infants within age range of 5-14 months. We have observed in also our study that difference between preoperative and postoperative acetabular indices was higher in the hips operated within age range of 3-12 months old.

The most critical complication monitored during treatment of DDH is AVH (6). A broad variety of incidence values of AVN ranging between $0 \%$ and $67 \%$ have ben reported in the studies conducted until present time in the literature (1,2,6-12) (Table 4).

Table 4. The rates of avascular necrosis in the literature $(1,2,6-12)$

\begin{tabular}{lc}
\hline & Avascular Necrosis \\
\hline Ferguson & $0 \%$ \\
Roose et al. & $0 \%$ \\
Kalamchi & $67 \%$ \\
Mergen et al. & $9.3 \%$ \\
Castillo and Sherman & $15 \%$ \\
Weinstein & $13.6 \%$ \\
Şener et al. & $26.5 \%$ \\
Mascio et al. & $8.3 \%$ \\
Konigsberg et al. & $27.5 \%$ \\
\hline
\end{tabular}

In our study, incidence of AVN was found as $10.7 \%$. Incidents of AVN in the age groups at surgery of $3-12$ and 13-18 months were approximately $7.1 \%$ and $3.6 \%$, respectively. Kiely et al. (13) have reported 4, 2 and 1 hips as Type I, Type 2 and Type3, respectively. We conclude that preserving medial circumflex femoral artery and its branches by a meticulously performed dissection will reduce risk for avascular necrosis considering the narrow surgical field.

Most commonly reported indications of additional surgical intervention after open reduction by the medial approach are redislocation, subluxation and acetabular dysplasia $(2,6,7,9,13)$. In this study, additional surgical intervention was needed due to subluxation and acetabular dysplasia in 2 and 6 hips, respectively. Incidents of additional surgical interventions show variety in the literature (Table 5) $(2,7-9,12-16)$.

In our study, additional surgery was needed in $28.6 \%$ of 28 hips with DDH. Incidence of need to additional surgery was found as $7.15 \%$ between 312 months of age at surgery whereas this rate was determined as $21.45 \%$ between $13-18$ months of age at surgery (Table 2).

In this study, excellent and good outcomes were obtained in $64.2 \%$ in 28 operated hips according
Table 5. The rates of additional surgery in the literature $(2,7-9,12-16)$

\begin{tabular}{lc}
\hline & $\begin{array}{c}\text { Additional surgical } \\
\text { intervention }\end{array}$ \\
\hline Castillo and Sherman & $35 \%$ \\
Mergen et al. & $27.9 \%$ \\
Sosna et al. & $85 \%$ \\
Matsushita et al. & $34 \%$ \\
Danielsson et al. ( $>12$ & $>50 \%$ \\
months) & \\
Şener et al. ( $\geq 18$ months) & $70 \%$ \\
Kiely et al. (6-23 months) & $22.4 \%$ \\
Mascio et al. ( $<12$ months) & $8 \%$ \\
Konigsberg et al. & $20 \%$ \\
\hline
\end{tabular}

to Severin's radiological assessment classification whereas insufficient outcomes were monitored in $35.8 \%$ of the operated hips. Castillo and Sherman, Kiely, Uçar, Mascio, Şener and Danielson have reported excellent and good outcomes in $73 \%$, $92 \%, \quad 79 \%, \quad 87.5 \%, \quad 50 \%$ and $99 \%$ cases, respectively $(7,8,12,13,16,17)$.

In our study, our evaluation according to modified McKay criteria revealed $78.6 \%$ excellent and $21.4 \%$ good hips, respectively. Pişkin et al. (3) have reported $82.5 \%$ excellent and $17.5 \%$ good outcomes in their case series of 40 hips. Sener et al. (12) have reported respectively $52.9 \%$ excellent and $29.4 \%$ good outcomes in their study involving age group of 18 months old and over.

As a conclusion, data obtained in the present study have suggested that satisfactory outcomes can be achieved by medial approach open reduction for $\mathrm{DDH}$ provided in the infants at 12 months old and lower ages at surgery.

As a consequence, medial approach open reduction for developmental dysplasia of the hip applying the Ferguson procedure is a simple and safe technique with its advantages such as lower blood loss, bilateral applicability in an identical session and low rates of avascular necrosis beside some disadvantages including a narrow surgical field and also labial swelling in the postoperative period. The results obtained in our study have suggested that medial approach open reduction may provide more favorable outcomes in the children at and under 12 months of age. Risk for surgical intervention increases as age of the patient advances therefore parents of the patients especially aged ranging between 13 to 18 months old should be necessarily informed about probable need for an additional surgery. 
Türközü et al / The outcomes of open reduction by the medial approach

\section{References}

1. Ferguson AB. Primary open reduction of congenital dislocation of the hip using a median adduktor approach. J Bone Joint Surg Am 1973; 55: 671-689.

2. Mergen E, Adyaman S, Omeroglu H, Erdemli B, Isiklar U. Medial approach open reduction for congenital dislocation of the hip using the Ferguson procedure. A review of 31 hips. Arch Orthop Trauma Surg 1991; 110: 169-172.

3. Pişkin A, Karaismailoğlu TN, Sı̆̆ırcı A. Gelişimsel Kalça Displazili Çocuklarda Medial Yaklaşımla açık Redüksiyon; 40 Kalçanın Orta Dönem Sonuçları O.M.U. Tip Dergisi 2005; 22: 18-24.

4. Severin E. Congenital dislocation of the hip; Development of the joint after closed reduction. J Bone Joint Surg Am 1950; 32-A: 507-518.

5. Mckay DW. A comparison of the innominate and pericapsuler osteotomy in treatment of congenital dislocation of the hip. Clin Orthop Relat Res 1974; 98: 124-132.

6. Kalamachi A, Schmidt TL, MacEwen GD. Congenital dislocation of the hip. Open reduction by medial approach. Clin Orthop Relat Res 1982; 169: 127-132.

7. Di Mascio L, Carey-Smith R, Tucker K. Open reduction of developmental hip dysplasia using a medial approach: A review of 24 hips. Acta Orthop Belg 2008; 74,3: 343-348.

8. Castillo R, Sherman FC. Medial adductor open reduction for congenital dislocation of the hip. J Pediatr Orthop 1990; 10: 335-340.

9. Konigsberg DE, Karol LA, Colby S, O'Brien S. Results of medial open reduction of the hip in infants with developmental dislocation of the hip. J Pediatr Orthop 2003; 23: 1-9.

10. Weinstein SL, Ponseti IV. Congenital dislocation of the hip. Open reduction through a medial approach. J Bone Joint Surg Am 1979; 61: 119-124

11. Roose PE, Chingren GL, Klaaren HE, Broock G. Open reduction for congenital dislocation of the hip using the Ferguson procedure. A review of twenty-six cases. J Bone Joint Surg Am, 1979; 61: 915-921.

12. Sener M, Baki C, Aydin H, Yildiz M, Saruhan S. The results of open reduction through a medial approach for developmental dysplasia of the hip in children above 18 months of age. Acta Orthop Traumatol Turc 2004; 38: 247-251.

13. Kiely N, Younis U, Day JB, Meadows TM. The ferguson medial approach for open reduction of developmental dysplasia of the hip. A clinical and radiological review of 49 hips. J Bone Joint Surg $\mathrm{Br}$ 2004; 86: 430-433.

14. Sosna A, Rejholec M. Ludloff's open reduction of the hip: long-term results. J Pediatr. Orthop 1992; 12: 603-606.

15. Matsushita T, Miyake Y, Akazawa H, Eguchi S, Takahashi Y. Open reduction for congenital dislocation of the hip: comparison of the long-term results of the wide exposure method and Ludloff's method. J Orthop Sci 1999; 4: 333-341.

16. Danielsson L. Late-diagnosed DDH: a prospective 11-year follow-up of 71 consecutive patients (75 hips). Acta Orthop. Scand 2000; 71: 232-242.

17. Ucar DH, Isiklar ZU, Stanitski CL, Kandemir U, Tumer Y. Open reduction through a medial approach in developmental dislocation of the hip: a follow-up study to skeletal maturity. J Pediatr. Orthop 2004; 24: 493-500. 